\title{
Investigating the Nature and the Structure and Functions of the Legislature in Iran
}

\author{
Fatemeh Ameri Seyahooei ${ }^{1} \&$ Mohammad Kazem Emadzadeh $^{2}$ \\ ${ }^{1}$ Bandar Abbas Branch, Islamic Azad University, Bandar Abbas, Iran \\ ${ }^{2}$ Department of Law, Faculty of Economics and Administrative Sciences, Isfahan University, Iran \\ Correspondence: Fatemeh Ameri Seyahooei, Bandar Abbas Branch, Islamic Azad University, Bandar Abbas, Iran. \\ E-mail: pnuba2000@gmail.com
}

Received: July 12, 2016 Accepted: August 18, 2016 Online Published: September 29, 2016

doi:10.5539/jpl.v9n8p119 URL: http://dx.doi.org/10.5539/jpl.v9n8p119

\begin{abstract}
Parliament is the basic pillar of a democratic society and as the most important legislative body in the country; it is considered the heart of democracy. Today, democracy will appear in the form of parliamentary and representation. The Iranian parliament, with 290 representatives, in terms of structure, has a unicameral system, but its legislative power is not simple. As a result, the legislature also enjoys wide powers and can withstand the abuse of executive power. The present study aims to investigate the nature and the structure and functions of the legislature in Iran. It should be noted that the method of data collection is observed and the nature of the study is descriptive.
\end{abstract}

Keywords: political structure, separation of powers, legislative, parliamentary and Iran

\section{Introduction}

The government, as one of the constituent elements, the outer manifestation and symbols of state and country authority includes a set of ruling institutions that each of them has their certain tasks. In an organic division of the government, the three major parts can be seen, which include: the legislature, the executive and the judiciary. In this regard, the legislature in various countries, plays an important role in creating a sustainable democracy, and is considered as one of the most essential foundations of democracy. Democratic societies need a place, so that the representatives of different communities come together in it and have a close communication and link with the masses. In addition, these institutions must have the ability to pass good and applicable laws to accelerate he public participation in the affairs. The legislative function is different according to the structure of the political system, the electoral system and party system in each country. In some countries, the legislative structure has a functional, non-functional and monitoring nature. In general, the legislature has supervision over the executive, and this supervision will be applied in different ways and with different functions. On the other hand, it is remarkable that Parliament is as the most important pillars of a democratic society and it is considered as the heart of democracy and most important source of the legislative body in the country. Following the formation of democratic systems in the world, and the creation of the separation of powers principle in government, parliament is considered as an essential component in such systems, and today in democratic systems, this pillar of the system plays a decisive and critical role in the national macro decision-making. Since the advent of the new democratic government, so far, what is known as democracy is more the representative democracy that is manifested in the form of Parliament. Therefore, parliament is the rule symbol and embodiment of the people's will. Thus, the Parliament, in the new political system, is based on democracy and the rule of law, and in the constitution, there are strong qualifications are defined for it and its independence has been recognized along with two of the judiciary and the executive. On the other hand, a new constitution of countries, knew the parliament represents the will of the people, which represents the whole nation. The creation of Parliament, by the vote of people and the authority given to the Parliament from the constitution is considered the most important step in establishing a democracy, where the will of the people in decision-making and macroeconomic policy will be manifested.

\section{Institutional Approach: Models for Theoretical Research Approach}

The study of political institutions can be started from different aspects. Essentially, institutionalism approach, 
both as a matter of content, related to the nature of institutions as well as a method and in the end, in the form of a theory may be considered. Many political scientists that mostly tend to classical traditions in this field believe that the main core of political analysis has formed on the existence of political institutions and their functioning. ${ }^{1}$ The Akshtain, Michael Oakeshott, Landau, Herman Finer, Daisy, Mackenzie, Johnson, Macridis, David Marsh and Monk Olson are named as institutional approach theorists. According to these theorists, institutions are one of the pillars of policies. According to Herman Finer, who is a pioneer in the institutional approach, political institutions are such as coral reefs, which are made with a conscious plan and grow together. In another dimension, Finer believes that the constitution is defined as the fundamental political institutions. In other words, political institutions are formed and emerged from the constitution. For example, institutions such as government, sovereignty, political dynamics system with the country's constitution, they undertake the political process. In addition, Finer placed his institutional analysis, both within the government framework and in the field of economics and history, as well. Finer claims the institutional approach scientific, and believes that, in the study, the government as a political entity, not only legally, but also performance, type and dynamics of government, should also be studied. ${ }^{2}$

Institutional approach is the subject that covers rules, procedures and official organizations of the government. An approach that uses lawyers and historians tools to explain the restrictions on political behavior and democratic performance and is a breeder of representative democracy liberal. Of course, it is clear that all those benefit from the approach do not believe the tips above, but all have sufficient points in common for this naming. ${ }^{3}$

\section{Study the Nature, Structure and Functions of Legislative in Iran}

\subsection{First Speech: The Nature of the Legislature of the Islamic Republic of Iran}

Islamic Republic of Iran legislative is an institute that rooted in public votes and in accordance with the documented basic criteria applies a significant share of power in the political system of a country. The legislature is the God-given right, is representing the general will of the people and the nation, in which social and political destiny of the people will be marked and after the collision of ideas, explore and discussion, exchange of ideas and finally obtaining a majority of votes in a documented set, their life program will be applicable. ${ }^{4}$

Constitution in expressing the sovereignty of the people has established the legislature's actions, in two ways:

A) Indirect actions of the legislature are through Parliament that is formed from elected representatives of the people and its decisions after passing legal process will be notified to the executive and the judiciary to run.

B) The critical issues in economic, political, social and cultural, the functions of the legislature may be happened by means of referenda and direct reference to the people's vote. Asking for referring to public votes must be approved by two-thirds of MPs. Thus, the legislature will be applied with the Parliament and the nation joint collaboration. Of course, despite the ongoing legislative institutions and the right of Parliament to legislate on all issues, there is no need to direct actions of the legislature. That is why, the date of the referendum, from the founding of the Islamic Republic of Iran, so far, shows no legislative referendum. However, the constitution has been taken the appealing to public votes as a political solution, in important cases into consideration. Islamic republic's referendum law, approved on 23.06.1989, which, apparently, was drafted in implementation of Article Fifty-Nine constitution, has limited the people's vote in two ways of yes and no. Given that, according to the principle stated, pursuant to the aforementioned poll after the approval of two-thirds of the delegates is possible, it can be concluded that, people have no role in designing the rules of composition, but only the president's suggestion or a hundred of representatives, which passed the House, will be approved or rejected. ${ }^{5}$

\subsection{Second Speech: The Nature of the Legislation in the Islamic Republic}

The structure and nature of Iran's legal are based on religious ideas and revelation system. So, the phenomenal source of its laws is very different with other countries and legal systems. One of the distinctions is in the legislature concept, because, "Legislation", in the Iranian law, means "explanation" and the legislature, in many cases of Islamic law, such as hudud and qisas and diya and sanctions, it approves them in codified form and the

\footnotetext{
${ }^{1}$ Finer, S. E. (1987). Herman, Finer, in V.Bogdanor (ed), The Blackwell Encyclopaedia of political Institutions (Oxford:Basil Blackwell).

${ }^{2}$ Diamond, Stanley (1974), In search of the primitive: A Critique of Cilvilization. New Brunswick,Transation Books.

${ }^{3}$ Marsh, David, Stoker, Gerry (2005) method and theory in political science, translator Amir Mohammad Haji Yousefi, Tehran, publication of the Institute for Strategic Studies, Second Edition.

${ }^{4}$ Hashemi, Mohammad, the Islamic Republic of Iran, Tehran, published in 2006, Page 85.

${ }^{5}$ Ibid., P. 86.
} 
Law and in new problems, also it regulates rules within the framework of the principles and conditions set forth in Islamic sources and these regulations and rules should never be in conflict with Islamic law, otherwise they are void. ${ }^{6}$

But the legal system of Islam has considered special importance for the people, and individuals in the community, and their satisfaction and willingness in forming the government is relevant, hence, the legislature, in addition to the legislative role (determination), which is the place of consensus and the rise of the social rules of the community, it is a place for public comments, too. For this reason, social protests, demands of the people, questioning and impeach of officials are possible in the parliament. Accordingly, the legislature and its foundations have duties and authority other than the legislature as well. ${ }^{7}$

\subsection{Third Speech: The Legislative Structure in the Islamic Republic of Iran}

The legislature of the Islamic Republic of Iran is based on the single parliament, meaning that, in our country, "absolute nation" irrespective of any distinction in religion, tribal and racial is considered by the constitution. So, accepting single-chamber legislature must be known as the integrity of the nation and equal rights of people, but this unicameral legislature has two distinct elements: the Parliament and the Guardian Council, without the existence and the synergies they apply the legislature is not possible. Therefore, the legislature Islamic Republic of Iran, the parliament formed a unit called the Parliament and the Guardian Council that without their existence and joint collaboration, applying legislature is not possible. So legislature of the Islamic Republic of Iran is formed from a unit House of Parliament called Islamic Consultative Assembly and the Guardian Council is its complementary and in fact, it is the main pillar of the unit parliament.

Based on the above, the legislative organs, the Legislature include:

1) The Parliament, in accordance with Article 71 of the constitution: Parliament on all matters, within the limits prescribed in the constitution to legislate.

2) Guardian Council constitution, the Guardian Council, has twelve members; six of whom, Supreme Leader Supreme Leader and six jurists are appointed. The Council, in accordance with Article 94 of the constitution, the parliament considers two aspects: the compatibility of the compatibility of the constitution with Islamic law. ${ }^{8}$

Based on the above, the legislative organs in the legislature include:

1) The Parliament, in accordance with Article 71 of the constitution: Islamic Consultative Assembly on all matters within the limits prescribed in the constitution can legislate.

2) Guardian Council constitution, the Guardian Council has twelve members that six of them are jurisconsult appointed by the Supreme Leader and six of them are lawyers. According to Article 94 of the constitution, this council will review the legislation from two aspects: the lack of compatibility with Islamic law - the lack of compatibility with the constitution. ${ }^{9}$

\subsection{Fourth Speech: Legislative Tools of Legislature}

First topic: Islamic Consultative Assembly

The Islamic Consultative Assembly is the legislative tool of the legislature. Given that, the Parliament is one of the ruling authorities and pillars of the regime, the lack of it, its closing or stopping in the government, will create pores and deficiency, therefore, in accordance with Article 63 of the law, elections for each session of parliament should be held before the end of the previous period, so that the country is never without an Assembly. In order to constitute an Islamic Consultative Assembly and does its duties and responsibilities, it requires the selection of representatives, certain organizational structures which, in this section, topics such as the representation, structure, duties, responsibilities and powers of the parliament will be discussed. ${ }^{10}$

The second topic: the position of parliament representative

According to Article 62 of the constitution, "the parliament is formed from the nation representatives, who are directly elected by secret ballot. Parliamentary elections will be performed for regional; however, each representative is one of the elected districts and should deal with problems in electoral area, but, according to the constitution, he is the representative of the entire nation and should decide and act on the country's issues and

\footnotetext{
${ }^{6}$ Electronic system of legal, legislative nature in the Islamic Republic, Tehran, 2009.

${ }^{7}$ Ibid.

${ }^{8}$ Electronic systems lawyer, the legislative branch in Iran, Tehran, 2011, p. 1.

${ }^{9}$ Hashemi, Mohammad, former Page 86.

${ }^{10}$ Lawyers electronic systems, tools legislative legislature, Tehran, 1388.
} 
other electoral districts. Article 84 of the constitution, in this regard says: "every representative is responsible to the entire nation and has the right to comment in all internal and external issues.

None of the representations can delegate their responsibilities to another, since according to Article 85 of the constitution, "the representative position is for the individual, and is not transferable to others." So, as each representative is elected by the people with specific qualifications and social character, this responsibility cannot be changed to another person, who is not qualified and has different characteristics.

It should be noted that, vested with the individual of being a representative does not confirm their personal and independent capacity in applying the rule, but the Parliamentary representatives will find existence and with legal personality independent of its members, apply the legislature. Representatives for the heavy responsibility that have in all of the country, on the basis of Article 67 of the constitution, must take the oath in the first meeting of the Assembly, to carry out the duties and the solemn responsibilities of representation and defense of religious principles, independence and territorial integrity, rights and freedoms and the nation.

According to Article 86 of the constitution, MPs, in the official duties of representation is completely free in the comments and their ratings, and cannot be pursued or seized them, because of the views or opinions in the parliament. Hence, representative responsibility requires the representatives have a kind of immunity in performing their duties to enable them explicitly stated their views with peace of mind and without any worries. However, it has been said that this immunity is not absolute and it is in the range of representation comment and duty and the use of it for other purposes and personal purposes, will not be eligible for immunity. Parliament period is four years and elected representatives in the midterm elections, the term of representation will be to the end of the period, but this period can be exceeded with the resignation or absence of representatives, the sooner than the moratorium. ${ }^{11}$

\subsection{The Fifth Speech: Functions of the Legislature in the Islamic Republic of Iran}

First topic: the authority of the legislature

The legislature in Iran, because of having monitoring tools, to control the government, is of great importance, so that, makes it closer to parliamentary regimes. We examine this observation, in two titles:

\section{A) Impact on executive}

According to the authority that the law gives to the legislature, we can say, this judiciary has the full authority to the executive and its major cause is because of the Cabinet members' responsibility for the Parliament that, in the following, we refer to a few of them:

1) Giving a vote of confidence to the Minister and Council of Ministers,

2) Asking, impeachment and dismissal of minister's authority,

3) The responsibility of the executive members of the legislature,

4) The impeachment of the president and announcing his political incompetence vote,

5) Approval Supervising,

6) Financial monitoring,

7) Legislation in the jurisdiction of Ministers,

8) The implementation of legislation by the government, ${ }^{12}$

B) The effect on the judiciary:

The legislature has a relative authority against the judiciary, which, this is due to the need for independence of the judiciary, in the end; the legislature has little influence on it.

1) Documentary verdict to laws by judges

2) Complaints attention from the judiciary in the committee of the Majles. ${ }^{13}$

The second topic: the supervision of the affairs of the country

The parliament, in addition to the duty of the legislature, has regulatory responsibility. The ways in which parliament uses to oversee the work place, in summary, are as follows:

\footnotetext{
${ }^{11}$ Ibid.

${ }^{12}$ Hashemi, Mohammad, the Islamic Republic of Iran, Tehran, published in 1385, Page 145.

${ }^{13}$ Ibid., P. 146.
} 
The first paragraph: monitoring (interference) of parliament in government formation

The parliament plays an important role in the formation of the executive. This means that after the introduction of Ministers, by the President, Parliament should give a vote of confidence for the ministry to them. Otherwise, the presented individuals cannot be responsible for ministry. ${ }^{14}$

The second paragraph: general supervision of representatives of government

Representatives in Islamic Council can monitor the work of the executive in several ways.

A) Note: Each of Representatives can warn verbally, if they see any violations of the law or neglecting of executives, or abuse in law enforcement matters in administrative units in a pre-orders speech, or through head parliament warn the ministers or presidents in writing notes. Providing answers from the people responsible in the government to the representative is required. ${ }^{15}$

\section{Conclusion}

According to Article 57 of the constitution in the Islamic Republic of Iran, "the ruling authorities in the Islamic Republic of Iran include: the legislature, executive and judiciary that are applied under the supervision of the Supreme command and leadership of the Ummah, in accordance with the principles of the future. These forces are independent from each other. The action has decreed the legislature in two ways. First, through indirect acts of the legislature through the Parliament and, secondly, legislative acts through a referendum and direct recourse to public vote. The structure and nature of Iran's legal are based on religious ideas and revelation system. Legislative tools of Iran legislature will be done through the parliament and the parliament's representative's position. Functions of the legislature in the Islamic Republic of Iran will be done by affecting on the Executive, the Judiciary and monitoring the affairs of the country.

\section{References}

Diamond, S. (1974). In search of the primitive: A Critique of Cilvilization. New Brunswick, Transation Books.

Electronic system of law. (2009). the nature of the legislation in the Islamic Republic. Tehran.

Electronic systems of lawyer. (2011). the legislative branch in Iran. Tehran.

Electronic systems of lawyers. (2009). legislative tools of the legislature. Tehran.

Finer, S. E. (1987). Herman, Finer. In V. Bogdanor (Ed.), The Blackwell Encyclopaedia of political Institutions. Oxford: Basil Blackwell.

Hashemi, M. (2006). the fundamental rights of the Islamic Republic of Iran. Tehran, Mizan publication.

Marsh, D., \& Stoker, G. (2005). method and theory in political science, translator Amir Mohammad Haji Yousefi, Tehran, publication of the Institute for Strategic Studies, Second Edition.

\section{Copyrights}

Copyright for this article is retained by the author(s), with first publication rights granted to the journal.

This is an open-access article distributed under the terms and conditions of the Creative Commons Attribution license (http://creativecommons.org/licenses/by/4.0/).

\footnotetext{
${ }^{14}$ Tehran lawyers electronic systems, supervisory functions of the legislature, Tehran, 1388.

${ }^{15}$ Ibid.
} 